\title{
The Millennium Development Goals and the social commitment of Nursing research
}

\author{
Letícia Becker Vieira ${ }^{a}$ \\ Helga Geremias Gouveiab \\ Wiliam Wegnerc \\ Luiza Maria Gerhardt ${ }^{\mathrm{d}}$
}

D0l: http://dx.doi.org/10.1590/1983-

1447.2015.01.53436

In 2000, the United Nations (UN) brought together representatives from 191 countries, heads of state and government at the UN Millennium Summit. The discussions outlined eight "Millennium Development Goals" (MDG) to be achieved by 2015. Driven by growing concerns for the planet's sustainability and the serious problems affecting humankind, the international community set goals targeted at priority areas to improve health and education conditions as well as reduce extreme poverty worldwide. The eight Millennium Development Goals are to: 1 - eradicate extreme poverty and hunger; 2 - achieve universal primary education; 3 - promote gender equality and empower women; 4 - reduce child mortality; 5 - improve maternal health; 6 - combat AIDS, malaria and other diseases; 7 - ensure environmental sustainability; and 8 - develop a global partnership for development.

The global commitment to the MDGs requires international cooperation and, locally, cooperation between the public and private sectors. These goals should be pursued by means of public policies and discussions and initiatives jointly carried out by people in different occupations, especially healthcare. Hence, the eight goals mutually reinforce and support one another as they represent basic human needs and seek to guarantee fundamental rights ${ }^{(1)}$.

As 2015 begins, it should be noted that Brazil has come a long way in terms of achieving the MDGs. The Brazilian performance is owed to social participation and a host of public social and healthcare policies put in place in the past few years that have had positive impacts on them. There are good indicators. However, many challenges still lay ahead ${ }^{(2)}$. The country realizes it is important to achieve these goals to foster the Brazilian population's health and welfare ${ }^{(3)}$.

Pursuing the MDGs along with researchers' dedication to topics involving worldwide development, whether economic, social or environmental, allow the civil society, the healthcare industry, and the government to work towards improving the quality of life of everyone across the country. There is a need for studies that actually create useful knowledge enabling social players and the government to attain important results for society by providing an updated, integrated view of the populations'life and health context (1).

This year marks the deadline set by the UN for the MDGs to be achieved, and the international community has been assessing the progress and defining a global development agenda for the post-2015 period. The world has changed significantly since the MDGs were ser in 2000, and the new agenda must reflect such changes in order to have a positive impact. It should be noted that, promisingly, there is broader consensus about several basic aspects such as the core place of people and human rights in development processes, as well as the urgent need to tackle the growing inequality in a wide variety of fields ${ }^{(4)}$.

These issues are also pertinent to the work routinely carried out in Nursing, which has been taking on commitments and responsibilities towards the sustainable development of populations worldwide. The International Council of Nurses is a federation of more than 130 national nurses'associations and has been encouraging its members to have nurses step up their efforts in pursuit of healthcare-related MDGs ${ }^{(5)}$. It is indisputable that the participation of nurses, the largest workforce in the field of health, has been essential for these goals to be achieved around the world.

\footnotetext{
${ }^{a}$ Doctor of Nursing by Escola de Enfermagem Anna Nery of Universidade Federal do Rio de Janeiro (EEAN-UFRJ). Professor at the Nursing Undergraduate Program of Universidade Federal do Rio Grande do Sul (UFRGS). ${ }^{b}$ Doctor of Health Sciences in the field of Maternal and Perinatal Health by Universidade Estadual de Campinas. Professor at the Nursing Undergraduate Program of Universidade Federal do Rio Grande do Sul (UFRGS). ' Doctor of Nursing by Universidade Federal do Rio Grande do Sul (UFRGS). Professor at the Nursing Undergraduate Program of Universidade Federal do Rio Grande do Sul (UFRGS).

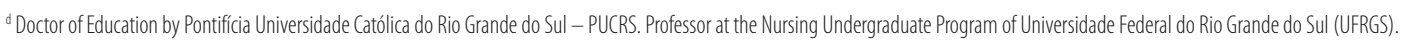


From this standpoint, nurses should conduct research using a variety of approaches that make it possible to analyze the progress and identify the challenges to be overcome/tackled in order to foster the populations' health, welfare, and peace. To that same extent, nurses can help by agents that disseminate knowledge and initiatives, reduce/fight social and health inequalities, and advance human rights.

Brazilian Nursing, as it commits to being a human and social practice in the everyday life of healthcare services and society, strives to decrease the inequalities that make it harder for people to obtain quality healthcare services. Therefore, we believe the topics contained in the MDGs are part of nurses' everyday practice and are consequently reflected in their scientific production. In education/training, care, management, and research, nurses are expected to put in their best efforts to ensure vulnerable, excluded populations are provided with all the care they need ${ }^{(6)}$.

In view of the foregoing, we ask: How has Brazilian nursing contributed to the achievement of MDGs? A brief survey of scientific productions in Rio Grande do Sul's nursing magazine Revista Gaúcha de Enfermagem (RGE) between 2000 and 2014 related directly and indirectly to the MDGs showed the existence of 100 publications. The survey was carried out by our reading the title and abstract of all papers published in the period. Then, the selected papers were categorized according to the eight MDGs.

Based on our survey, we found the highest number of scientific productions were dedicated to goal no. 6 - combat AIDS, malaria and other diseases $(n=31)$. With respect to maternal and child health, we tallied a total of 52 papers, while 29 were related to goal no. 4 - reduce child mortality, and 23 to no. 5 - improve maternal health.

A lower number of papers were published on the other MDGs: no. 3 - promote gender equality and empower women $(n=9)$, no. 7 - ensure environmental sustainability $(n=5)$, and no. 8 - develop a global partnership for development $(n=3)$. Goals nos. 1 - eradicate extreme poverty and hunger and 2 - achieve universal primary education were not the subject of any publications.

From this brief analysis of RGE papers, we found there is a need to steer Nursing research towards helping improve the MDGs' epidemiological and social indicators. We have also found the need to address topics that are either not or hardly ever looked into but which represent gaps in Nursing knowledge, such as strategies to fight hunger and extreme poverty and achieve universal primary education.

In order to help disseminate healthcare knowledge and considering Nursing's social commitment to towards the achievement of the MDGs internationally agreed upon in 2000 and about to be updated for the coming 15 years, RGE is putting together a themed Special Issue featuring papers that show the contribution provided by Nursing and nurses up to this time. Therefore, we are inviting researchers to submit MDG-related papers by June 30, 2015, to be published in volume 36, no. 4, of December 2015.

\section{口EFERENCES}

1. Jiménez LCV, Prada JRR. Los objetivos de desarrollo del milenio (ODM) de las naciones unidas: ¿en dónde estamos y para dónde vamos? fuente de inspiración para priorizar las labores desde la academia. Rev Lasallista Investig. 2011;8(1):126-35.

2. ODM Brasil [Internet]. Brasília: Presidência da República; c2009-15 [citado 2015 jan. 07]. Disponível em: http://www.odmbrasil.gov.br

3. Laurenti R. Objetivos de desenvolvimento do milênio. Rev Assoc Med Bras. 2005;51(1):3-4.

4. Ferreira PM. A agenda pós-2015 para o desenvolvimento: da redução da pobreza ao desenvolvimento inclusivo? [Internet]. Lisboa: Instituto Marquês de Valle Flôr; 2013 [citado 2015 fev. 5]. Disponível em: www.imvf.org/ficheiros/IMVFPolicyPaper_pos2015.pdf

5. Conselho Internacional de Enfermeiros (CH). Combater a desigualdade: objetivos de desenvolvimento do milénio 8,7,6,5,4,3,2,1 [Internet]. Genebra; 2013 [acesso em 2015 fev. 5]. Disponível em: www.ordemenfermeiros.pt/publicacoes/documents/kit_die_2013.pdf

6. Mendes IAC. A saúde no Brasil e América Latina: as metas do milênio da ONU e o papel da enfermagem. Rev Latino-Am Enfermagem. 2004;12(6):845-50. 